\title{
Model of diagnostics of resource efficiency in oil and gas sector of economy of Ukraine
}

\author{
Nadiia Shmygol 1,*, Władysława Łuczka ${ }^{2}$, Olena Trokhymets $^{3}$, Dariusz Pawliszczy ${ }^{4}$, and Ruslan Zavgorodniy ${ }^{3}$ \\ ${ }^{1}$ Zaporizhzhya National University, Department of Accounting and Taxation, 66 Zhukovsky Str., Zaporizhzhia, 69600, Ukraine \\ ${ }^{2}$ University of Life Sciences in Poznań, Department of national economy, 28 Polish Army Str., Poznan, 60-637, Poland \\ ${ }^{3}$ Classic Private University, Department of national economy, marketing and international economic relations, 70 Zhukovsky Str., \\ Zaporizhzhia, 69600, Ukraine \\ ${ }^{4}$ Gromadka Commune Office, 9 General Wł. Sikorskiy Str., Gromadka, 59-706, Poland
}

\begin{abstract}
The authors of the article determined that a number of scientists were involved in the development of a balanced system of indicators of the development of the oil and gas sector. Though an urgent scientific problem that needs further consideration is the development of a model of resource efficiency diagnostics in the oil and gas sector of the economy of Ukraine, taking into account the peculiarities of statistical monitoring. In order to solve this problem, the authors used methods of economic analysis, the method of rationing to bring the indicators to a comparative meaning, the method of additivemultiplicative compression, statistical methods of estimating variation and so on. The scientific novelty of the paper is: this study improved the model of diagnostics of resource efficiency in oil and gas sector in the economy of Ukraine based on the additive-multiplicative compression of the formed system, which, unlike the existing ones, takes into account their variation while defining weighting coefficients which show the experts' system of preferences.
\end{abstract}

\section{Introduction}

According to 2018 the oil and gas sector of Ukraine provided more than $40 \%$ of the economy's needs for energy resources. At the same time oi and gas sector accounted for $42.2 \%$ of total consumption. Due to high dependency, the research of many domestic scientists is devoted to various aspects of the operation of oil and gas extraction and processing enterprises.

The main tendencies of development and value of innovative technologies in the oil and gas sector were studied in [1-3].

The concept of resource efficiency in the modern and current practice of economic activity analysis has been widespread, since the efficient consumption of economic resources of any kind is associated, first of all, with intensive economic growth. That is why, the authors of [4-8] addressed the issues of ensuring a resource-efficient economy as a necessary condition for sustainable development.

Management of any economic system is always based on its current state, the definition of which is a separate scientific task. Therefore, various scientists were involved in the methodological bases of economic diagnostics, including the development of a balanced system of indicators for the development of the oil and gas sector [912].

This demonstrates that the scientific problem that needs to be solved in the framework of this research is the development of a model of resource efficiency diagnostics in the oil and gas sector of the economy of Ukraine, taking into account the existing peculiarities of statistical monitoring by the State statistical authorities.

The methods of economic analysis for estimation of resource efficiency, normalization method for bringing indicators to comparative appearance, method of additivemultiplicative compression for generalization of results in different directions of evaluation, statistical methods of estimation of variation for substantiation of values of weight coefficients in the model of diagnostics were used.

\section{Peculiarities of the measurement of resource efficiency in oil and gas sector of economy of Ukraine}

The peculiarities of the measurement of resource efficiency in oil and gas sector of economy of Ukraine include:

1. The available volume of input statistics on the basis of the State Statistics Service of Ukraine reports, with free access, significantly limits the possibilities for comprehensive assessment of the resource efficiency by all types of economic resources used in public production. 2. The change in methodology of organization of statistical observation during the recent years, and, accordingly, reporting instruments and documentation do not allow to carry out a retrospective analysis of resource efficiency indicators over a long-term period. The geopolitical changes that occurred in 2014 in the South-

Corresponding author: nadezdash@ua.fm 
East of Ukraine resulted in temporary occupation of the Crimea and parts of Donetsk and Luhansk Regions, have undoubtedly had a significant impact on the oil and gas sector activity as well. That is why comparative analysis of the time periods cannot provide with objective information on the dynamics of the target indicators due to alterations in the special aggregate according to which they are calculated.

3. Some of the input data for 2016-2018 are not shown in the State Statistic Service reports due to its confidential status. First of all, it concerns assets conditions, volume of production and corresponding costs, fixed assets and a number of employees, financial results of crude oil production, natural gas extraction and production of refine products [13-14].

4. Any diagnostics in economic analysis is possible if there is a respective base of comparisons. In scoring models of diagnostics such a turning point are the classes of indicators stability; in the models of multiplicative discriminant analysis - the intervals of stability of integral index that determine the probability of the bankruptcy of economic entities; in the express-analysis - industry standards and cross-industry comparisons; in complex analysis - dynamics and plan value of indicators, industry standards etc. As for the oil and gas sector of the economy, for the diagnostics of its resource efficiency considering available data, we will use cross-industry comparison and analysis of time periods applying methods of statistic theory.

\section{Indicators of the model of resource efficiency in oil and gas sector of economy of Ukraine diagnostics}

Thus, taking into account the leading experience of analysis of economic activity [15-26] and mentioned above peculiarities of information support, a model of diagnostics of resource efficiency of oil and gas sector of the economy of Ukraine has a set of indicators as its basis, which consist of the following areas of assessment: material resources, fixed assets, labor resources and aggregate capital. Let's consider them in more detail.

1. Material resources $\left(M R_{1}\right)$. Technological underdevelopment (backwardness), associated with initial processing of resources, is always characterized by low added value and high material (output) ratio. That is why effective use of material resources is the priority in the development not only of oil and gas sector, but of the economy of Ukraine. This group consists of the following indicators:

- material productivity $\left(K_{11}\right)$ - characterizes the volume of output of the inquiry period by 1 UAH of material costs. This indicator should be maximized and is calculated by the formula:

$$
K_{11}=\frac{V O_{1}}{M C_{1}},
$$

where $V O_{1}, M C_{1}$ - accordingly, volume of output and material costs in the inquiry period.
- net profit (income) for $1 \mathrm{UAH}$ of material costs $\left(K_{12}\right)$, should be maximized. According to its economic essence, this indicator is the analogue of cost effectiveness (profitability), which allows to evaluate the efficiency of raw materials and supplies in the process of profit generation in the enterprises of the industry:

$$
K_{12}=\frac{N P_{1}}{M C_{1}},
$$

where $N P_{1}$ - net profit in the inquiry period.

- coefficient of correlation of the growth rate of product output and material costs $\left(K_{13}\right)$. Intensive economic development involves obtaining the final result not due to the greater consumption of resource productivity. That is why this coefficient should be $K_{13}>1$.

$$
K_{13}=\frac{V P O_{1}}{V P O_{0}}: \frac{M C_{1}}{M C_{0}},
$$

where $V P O_{0}, M C_{0}$ - accordingly, volume of product output and material costs in base period.

- the share of material costs in the cost of production $\left(K_{14}\right)$. According to 2018, material costs for the economy in general were $74,3 \%$ from the cumulative costs (total costs) for production output. Accordingly, depreciation accounted for $6,7 \%$, labor costs $-14,1 \%$, benefits related deduction $-2,9 \%$, and other costs $-2,0 \%$ from cumulative costs (total costs).

As we can see, the high share of material costs - is a system problem for the entire economy of Ukraine. It indicates not only the low level of social production, but also hinders increase in wages and living standards of the population. That I why this indicator should be minimized and calculated by the formula:

$$
K_{14}=\frac{M C_{1}}{V C C P_{1}}
$$

where $V C C P_{1}$ - volume of cumulative costs (total costs) for production in the inquiry period.

The main production factors which are part of economic resources, are fixed assets and labor resources (human capital). In most cases they determine the production capacity of business entities and industries of the economy in general.

According to the results of 2018, the residual value of fixed assets in Ukraine was 3783.5 billion UAH, and the volume of production - 6207.7 billion UAH. Accordingly, return on assets was $1.64 \mathrm{UAH}$. The number of employed population for the same period was 16360.9 thousand persons. Thus, the annual labor productivity was 379.4 thousand UAH per employee or 31.6 thousand UAH monthly.

Thus, complex diagnostics of the resource efficiency of oil and gas sector should include comparative assessment in these areas.

2. Fixed assets $\left(K_{2}\right)$. This group includes the following indicators:

- return on assets $\left(K_{21}\right)$ - characterizes the volume of production output for the inquiry period at the rate of 1 UAH of residual value of fixed assets, and should be maximized: 


$$
K_{21}=\frac{V O_{1}}{F A_{1}}
$$

where $F A_{1}$ - the value of fixed assets in the inquiry period.

- return on assets $\left(K_{22}\right)$ - equals the net profit on $1 \mathrm{UAH}$ of residual value of fixed assets, and it should be maximized:

$$
K_{22}=\frac{N P_{1}}{F A_{1}}
$$

- coefficient of correlation of the growth rate of product output and fixed assets costs $\left(K_{23}\right)$. Intensive development implies an increase in aggregate production output not at the expense of additional production capacity attraction, but due to the return on assets increase. That is why this coefficient should have the inequality $K_{23}>1$.

$$
K_{23}=\frac{V O_{1}}{V O_{0}}: \frac{F A_{1}}{F A_{0}}
$$

where $F A_{0}$ - residual value of fixed assets in base period.

3. Labor resources $\left(K_{3}\right)$. The indicators of resource efficiency of this group include:

- labor productivity $\left(K_{31}\right)$ - characterizes the production output for the inquiry period per one employee and should be maximized:

$$
K_{31}=\frac{V O_{1}}{A A E P_{1}}
$$

where $A A E P_{1}$ - average annual number of employed population in the inquiry period.

- ROI of employees $\left(K_{32}\right)$ - equals net profit per one employee, and should be maximized:

$$
K_{32}=\frac{N P_{1}}{A A E P_{1}},
$$

- share of labor costs in the cost of production $\left(K_{33}\right)$. According to statistics, in most of Eurozone countries this indicator is $30-35 \%$, which is more than 2 times ahead of the similar level of the economy of Ukraine. That is why one of the reserves for the growth of the average level of remuneration of labor is adjustment of the production cost structure, and should be maximized $K_{33}$ :

$$
K_{33}=\frac{R L_{1}}{V C C P_{1}}
$$

where $R L_{1}$ - amount of remuneration of labor cost in the inquiry period.

Aggregate capital is generated from both equity and borrowed sources and is allocated to fixed assets and current assets and is also an economic resource and a focus of the researches interest in terms of its effective use.

4. Aggregate capital (total capital) $\left(K_{4}\right)$. In order to characterize the efficiency of capital use, in the practice of financial analysis, along with profitability indicators, indicators of turnover and duration of turnover are calculated. Let's consider them in more detail.

- aggregate capital (total capital) turnover $\left(K_{41}\right)-$ shows how many the income of the inquiry period exceeds the corresponding amount of the raised total capital The increase in turnover shows an increase of its use:

$$
K_{41}=\frac{C I_{1}}{C K_{1}}
$$

where $C I_{1}$ - cumulative income of the inquiry period from all types of economic activity; $C K_{1}-$ average annual amount of capital of the inquiry period, taking into account own and borrowed sources of income.

- return on aggregate capital (total capital) $\left(K_{42}\right)$. Any borrowed capital, involved in the activity of business entities, has its price. The condition of the expediency of its use is always the excess of return on aggregate capital (total capital) over the weighted average price of the loan. Otherwise, according to financial leverage effect, economic activity will lead to a gradual decrease in equity.

$$
K_{42}=\frac{B P_{1}}{C K_{1}},
$$

where $B P_{1}$ - balance (gross) profit of the inquiry period, excluding income tax.

- duration of circulation of aggregate (total) capital $\left(K_{43}\right)$ - shows how many days it will take for the income received during economic activity to be equal to the amount of attracted aggregate (total) capital Speeding up the turnover means reduction of the duration of circulation and vice versa. The formula for $K_{43}$ calculation is the following:

$$
K_{43}=\frac{365}{K_{41}},
$$

In the numerator, in this case, there is a number of days for the inquiry period.

Fixed assets form production capacity of the economic entities and do not directly participate in the circulation. The efficiency of the use of aggregate (total) capital is directly influenced by the turnover of the operating capital according to the formula:

$$
K_{44}=\frac{C I_{1}}{O C_{1}}
$$

where $O C_{1}$ - average annual amount of the operating capital in the inquiry period.

- duration of operation capital turnover $\left(K_{45}\right)$ - shows how many days it will take for the received income to be equal to the amount of operating capital and is calculated by the formula:

$$
K_{45}=K_{43} \times \frac{O C_{1}}{C K_{1}}
$$

Thus, we have formed a system of indicators for assessing the resource efficiency of oil and gas sector of the economy of Ukraine taking into account available statistics. Taking into account that all the indicators are relative indicators we will use cross-industry comparisons for diagnostics of its condition.

By direct comparison we have an opportunity to define competitive advantages or backlog of the oil and gas sector by every indicator. However, summarizing the results of such multifactor evaluation requires the 
corresponding compression based on the integrated index. For this reason, first of all, it is necessary to bring the value of all indicator of resource efficiency to one base of comparison, which means to normalize them. The current practice of rationing involves setting up values to the range $[0 ; 1]$ using formula:

$$
K^{\prime}=\frac{K-K_{w}}{K_{b}-K_{w}}
$$

where $K, K^{\prime}$ - accordingly, input and normalized value of resource efficiency indicator, which belong to i group; $K_{w}$, $K_{b}$ - accordingly, the worst and the best value of the indicator $K$, among other industries.

Since there are some indicators that should be maximized as well as minimized, then to determine the worst indicators $K_{w}$ and the best indicators $K_{b}$ we should follow the rule:

- if $K$ should be maximized, then $K_{b}=\max (K), K_{w}=\min (K)$; - if $K$ should be minimized, then $K_{b}=\min (K), K_{w}=\max (K)$.

The use of formula (16), observing the rule, allows to arrange the normalized values of indicators in such a way that the best value of indicator corresponds with the normalized and vice versa.

With its help, each of the indicators (1) - (15) is reduced to a comparative form. The compression of normalized values to group and integral indexes is based on the additive-multiplicative model:

$$
\begin{gathered}
I P E=\sum_{i=1}^{n}\left(a_{i} \times K_{i}\right) \\
K_{i}=\sum_{j=1}^{m_{i}}\left(a_{i j} \times K_{i j}^{\prime}\right),
\end{gathered}
$$

for all $i=1 \ldots n$,

where IPE - integral index of resource efficiency; $K_{i}, a_{i}-$ accordingly, summary (consolidated) index of resource efficiency of i group and its weighing coefficient; $K_{i j}^{\prime}, a_{i j}-$ accordingly, normalized $\mathrm{j}$ indicator of $\mathrm{i}$ group and its weighing coefficient; $n$ - a number of indicator groups; $m_{i}-$ a number of indicators of $i$ group.

There are certain limitations for weighing coefficients $a_{i}$ and $a_{i j}$. First of all, their values should range from 0 to 1 ; second of all, the sum of coefficients of a certain group should equal 1 .

\section{Diagnostics of the resource efficiency of oil and gas sector of the economy of Ukraine}

There are different approaches to estimating weights of coefficients, depending on the system of advantages of expert's or group of experts' who make decisions. In this study we will focus on the method which is used by the researchers while compiling different international indices with the purpose of comparison, in particular, international ecology efficiency index [14-15].

In particular, we will proceed from the fact that in order to ensure equal influence of individual indicators on group, their root-mean-square deviations considering the weighting coefficients must be equal each other: $\sigma\left(a_{i} K_{i}\right)=\sigma\left(a_{j} K_{j}\right)$, for all $i \neq j$, or $\sigma\left(a_{i j} K_{i j}\right)=\sigma\left(a_{i j} K_{i z}\right)$, for all $i=1 \ldots n, j \neq z$.

If, according to experts' preferences, individual indicators should have different impact on the group or integral index of resource efficiency, this should also be respectively reflected in proportion between root-meansquare deviation of these indicators taking into account their weighting coefficients.

Considering the mentioned above information, we have obtained a system of equations using numerical method for diagnostics of resource efficiency in oil and gas sector in the economy of Ukraine, taking into account equal influence of indicators, which allowed to present a more detailed equation (18):

$I P E=0.328 K_{1}+0.261 K_{2}+0.244 K_{3}+0.167 K_{4}$

$K_{1}=0.162 K_{11}+0.267 K_{12}+0.452 K_{13}+0.119 K_{14}$

$K_{2}=0.325 K_{21}+0.318 K_{22}+0.358 K_{23}$

$K_{3}=0.290 K_{31}+0.354 K_{32}+0.356 K_{33}$

$K_{4}=0.183 K_{41}+0.241 K_{42}+0.191 K_{43}+0.210 K_{44}+0.174 K_{45}$

In determining the weighting coefficients in equation $K_{1}$, the variation for each indicator was: $\sigma\left(a_{1 j} K_{1 j}^{\prime}\right)=0.036$ for all $j=1 . . .4$; in the equation $K_{2}-\sigma\left(a_{2 j} K_{2 j}^{\prime}\right)=0.085$ for all $j=1 . . .3$; in the equation $K_{3}-\sigma\left(a_{3 j} K_{3 j}^{\prime}\right)=0.068$ for all $j=1 \ldots 3$; in the equation $K_{4}-\sigma\left(a_{4 j} K_{4 j}^{\prime}\right)=0.048$ for all $j=$ $1 \ldots 5$; in the equation $\operatorname{IPE} \sigma\left(a_{i} K_{i}\right)=0.321$ for all $i=1 . . .4$.

As oil and gas companies are a part of mining and processing industry, it is appropriate to use cross-industry comparison with these industries and with the economy in general.

Taking into account the developed model (18), the results of diagnostics of resource efficiency for 20152018 are presented in table 1.

In the table 1 the symbol "*" marks the types of economic activity which are a part of oil and gas sector. As for the separate crude oil production and natural gas extraction, and refined products production in 2018 as well, the access to the relevant statistics is limited due to their confidential character.

\section{Conclusions}

Analysis of the dynamics of oil and gas production shows that during 2015-2018 these enterprises significantly improved their indicators of resource efficiency on all the areas of research, resulting in an integral index increase from 0.404 to 0.658 , which is positive. Significant qualitative shifts occurred in consumption of raw materials and supplies and labor resources use. The result of such changes was that the oil and gas sector outperformed both the primary (extraction) industry and the entire industry, as well as the average level in the economy of Ukraine in terms of resource efficiency. Thus, on the one hand, we had a positive trend in resource efficiency increase. On the other hand, it was achieved by a significant increase in product prices in recent years. 
Table 1. The results of diagnostics of the resource efficiency of oil and gas sector of the economy of Ukraine according of data of 2015-2018 years.

\begin{tabular}{|c|c|c|c|c|c|c|}
\hline $\begin{array}{l}\text { Industries } \\
\text { of the economy }\end{array}$ & Years & $P_{1}$ & $P_{2}$ & $P_{3}$ & $P_{4}$ & $I P E$ \\
\hline \multirow{2}{*}{ Total } & 2015 & 0.293 & 0.345 & 0.260 & 0.306 & 0.301 \\
\hline & \begin{tabular}{|l|}
2018 \\
\end{tabular} & 0.316 & 0.388 & 0.334 & 0.466 & 0.364 \\
\hline \multirow{2}{*}{ Industry } & 2015 & 0.281 & 0.360 & 0.233 & 0.540 & 0.333 \\
\hline & 2018 & 0.297 & 0.435 & 0.327 & 0.661 & 0.401 \\
\hline \multirow{2}{*}{$\begin{array}{l}\text { Mining industry (pri- } \\
\text { mary sector) and quar- } \\
\text { rying }\end{array}$} & 2015 & 0.300 & 0.382 & 0.283 & 0.483 & 0.348 \\
\hline & 2018 & 0.391 & $0.468 \mid$ & 0.500 & 0.670 & 0.484 \\
\hline \multirow{2}{*}{$\begin{array}{l}\text { Crude oil and natural } \\
\text { gas production }\end{array}$} & 2015 & 0.372 & 0.406 & 0.266 & 0.666 & 0.404 \\
\hline & 2018 & 0.667 & 0.468 & 0.786 & 0.751 & 0.658 \\
\hline Crude oil production ${ }^{*}$ & 2015 & 0.276 & 0.252 & 0.252 & 0.500 & 0.301 \\
\hline $\begin{array}{l}\text { Extraction of natural } \\
\text { gas }^{*}\end{array}$ & 15 & 0 & 0 & 20 & 85 & 99 \\
\hline \multirow{2}{*}{$\begin{array}{l}\text { Provision of ancillary } \\
\text { services in the field of } \\
\text { oil and natural gas }\end{array}$} & 2015 & 0.306 & 0.252 & 0.345 & 0.577 & 0.347 \\
\hline & 2018 & 0.300 & 0.735 & 0.395 & 0.861 & 0.530 \\
\hline \multirow{2}{*}{ Processing industry } & 2015 & 0.272 & 0.387 & 0.213 & 0.609 & 0.344 \\
\hline & \begin{tabular}{|l|}
2018 \\
\end{tabular} & 0.285 & 0.542 & 0.300 & 0.748 & 0.433 \\
\hline $\begin{array}{l}\text { Production of oil pro- } \\
\text { cessing }\end{array}$ & 2015 & 0.255 & 0.503 & 0.223 & 0.733 & 0.392 \\
\hline \multirow{2}{*}{$\begin{array}{l}\text { Gas production, distri- } \\
\text { bution of gaseous fuel } \\
\text { through local pipelines }\end{array}$} & 2015 & 0.312 & 0.593 & 0.366 & 0.190 & 0.378 \\
\hline & 2018 & 0.243 & 0.2 & 0.350 & 0 & 0.272 \\
\hline
\end{tabular}

Regarding the oil and gas refining, as well as gas distribution system we can observe that according to the indicators of fixed assets and capital use there is a significant lag from other enterprises of the processing industry and average level in the economy in general.

Thus, the diagnostics of resource efficiency of oil and gas sector pointed to existing problems faced by refinery enterprises and significant improvement in oil and gas production field.

This study improved the model of diagnostics of resource efficiency in oil and gas sector in the economy of Ukraine based on the additive-multiplicative compression of the formed system, which, unlike the existing ones, takes into account their variation while defining weighting coefficients which show the experts' system of preferences.

\section{References}

1. A. Karev, Top Trends in the Oil and Gas Sector. J Petrol. Tech. 65, 102-106 (2015). doi: 10.2118/09130102-JPT

2. K.N. Milovidov, Global investment in upstream oil and gas sector. Probl. Econ. Manag. Oil Gas Compl. 46-54 (2019). doi:10.33285/1999-6942-20192(170)-46-54.

3. S. Nechully, S.K. Pokhriyal, S.E. Thomas, Inter. J. Mech. Eng. Tech. 9, 236-252 (2018)

4. D. Danilovich, Optimising energy sourcing and consumption in the oil and gas sector. AP. J. (2018). doi:58. 538. 10.1071/AJ17104
5. L. Rijnhout, M. Stoczkiewicz, M. Bolger, Necessities for a Resource Efficient Europe (Springer, 2018). doi:10.1007/978-3-319-50079-9_2

6. M. Hirschnitz-Garbers, F. Montevecchi, A. Martinuzzi, Resource Efficiency (Springer, 2012). doi:10.1007/978-3-642-28036-8_728

7. F. Ferreira, A. German (eds.), Advanced Methodologies for a Circular Economy. Resource Efficiency and Sustainability. Appl. Sc. J. (2019)

8. R. Berkel, Z. Fadeeva, Role of Industries in Resource Efficiency and Circular Economy. Paper presented at the 8th International Conference on Sustainable Waste Management, At Vijayawada, India, 22 November 2018

9. Ch. Nortje, S. Middelberg, M. Oberholzer, B. Pieter. Env. Ec. 5, 31-39 (2014)

10. D. Rodrik, A Research Agenda in Economic Diagnostics. Dig. SSRN El. J. (2010). doi:10.2139/ssrn.1889365

11. O. Tolpegina, Methodological principles of classification of types of economic diagnostics. Eff. Cr. Manag. 64-73 (2017). doi:10.17747/2078-88862017-1-2-64-73

12. T. Mantserova, D. Lapchenko, The Main Approaches to Economic Diagnostics of the Power Engineering Enterprises. ENER.. Pr. CIS H. Educ. Insti. P. Eng. Assoc. 62(4), 362-376 (2019). doi:10.21122/10297448-2019-62-4-362-376.

13. Ekonomichna statystyka: diialnist pidpryiemstv. Derzhavna sluzhba statystyky Ukrainy (Economic statistics: activity of enterprises. - State Statistics Service of Ukraine) (2019), http://www.ukrstat.gov.ua/operativ/menu/menu_u/sz e.htm. Accessed 02 Feb 2020

14. A.O. Fryzorenko (ed.) Polyvno-enerhetychni resursy Ukrainy. Statystychnyi zbirnyk. Derzhavna sluzhba statystyky Ukrainy (Ukraine's fuel and energy resources. Statistical collection. State Statistics Service of Ukraine). (Kyiv, 2019).

15. G.V. Savitskaya, Metodika kompleksnogo analiza hozyaystvennoy deyatelnosti (Methodology of a comprehensive analysis of economic activity). (INFRA-M, Moscow, 2007)

16. Environment Performance Index. Methodology. Yale Center for Environmental Law \& Policy, https://epi.envirocenter.yale.edu/2018-epireport/methodology. Accessed 02 Feb 2020

17. N. Shmygol, O. Galtsova, I. Varlamova, Developing a methodology to assess the environmental and economic performance index based on international research to resolve the economic and environmental problems of Ukraine. B. J. Econ. St. 4, 366-375 (2018). doi:10.30525/2256-0742/2018-4-4-366-375

18. V. Boiko, A. Kwilinski, M. Misiuk, L. Boiko, Competitive advantages of wholesale markets of agricultural products as a type of entrepreneurial activity: the experience of Ukraine and Poland. Ec. 
An.-XXI. 175(1-2), 68-72 (2019). doi:10.21003/ea.V175-12

19. T. Savchenko, N. Basiurkina, O. Rodina, A. Kwilinski, Improvement of the assessment methods of product competitiveness of the specialized poultry enterprises. Manag. Th. St. Rur. Bus. Infr. Dev. 41(1), 43-61 (2019). doi:10.15544/mts.2019.05

20. I. Perevozova, N. Shmygol, D. Tereshchenko, K. Kandahura, O. Katerna, Introduction of creative economy in international relations: aspects of development security. J. Sec. Sust. 9(1), 139-154 (2019). doi:10.9770/jssi.2019.9.1(11)

21. O.V. Cherniavska, V.V. Tomareva, T.Iu. Oharenko, Otsinka vplyvu moralnoho ryzyku na sotsialnu vidpovidalnist biznesu na osnovi kohnityvnoho modeliuvannia (Assessment of the impact of moral risk on corporate social responsibility based on cognitive modeling). (KhDU, Kharkiv, 2017)

22. K. Pająk, O. Kvilinskyi, O. Fasiecka, R. Miśkiewicz, Econ. Env. 2(61), 122-138 (2017)

23. A. Pinchuk, N. Tkalenko, V. Marhasova, Implementation of Circular Economy Elements in the Mining Regions. E3S Web of Conferences 105, 04048 (2019)

24. J. Polcyn, S. Stepien, A. Tosovic-Stevanovic, Econ. Soc. Dev. 111-121 (2018)

25. V. Tkachenko, A. Kwilinski, O. Korystin, N. Svyrydiuk, I. Tkachenko, Assessment of information technologies influence on financial security of economy. J. Sec. Sust. 8(3), 379-390 (2019). doi:10.9770/jssi.2019.8.3(7)

26. A. Kwilinski, I. Ruzhytskyi, V. Patlachuk, O. Patlachuk, B. Kaminska, J. Leg. Eth. Reg. Iss. 22(2S) (2019) 